\title{
IAMJ
}

INTERNATIONAL

AYURVEDIC

MEDICAL JOURNAL

\section{A COMPARATIVE CLINICAL STUDY OF MATRAVASTI AND PICHU WITH RASNA TAILA IN SANDHIGATAVATA W.S.R TO OSTEOARTHRITIS}

\author{
Nupur Biswas ${ }^{1}$, Kultar Singh ${ }^{2}$ \\ ${ }^{1}$ Lecturer, ${ }^{2}$ Professor \\ ${ }^{1,2}$ Kunwar Shekhar Vijendra Ayurved Medical College \& Research Center, Gangoh, Uttar Pradesh, India
}

Corresponding Author: nupurbiswas1953@gmail.com

\section{https://doi.org/10.46607/iamj0909122021}

(Published Online: December 2021)

Open Access

(C) International Ayurvedic Medical Journal, India

Article Received: 30/11//2021 - Peer Reviewed: 02/12/2021 - Accepted for Publication 07/12/2021

\section{Check for updates}

\begin{abstract}
Sandhigata Vata (Osteoarthritis) is a type of Vatavyadhi (degenerative disease) that mainly occurs in Vriddhavastha (Old age) due to Dhatukshaya (cellular degeneration). Vagabhatta has also considered Vata Vyadhi as a Maharoga. It appears from the point of view of modern medical sciences that Sandhigata vata can be simulated with Osteoarthritis in its clinical appearance. Osteoarthritis is the most common articular disorder that begins asymptomatically in the $2^{\text {nd }}$ and $3^{\text {rd }}$ decades and is extremely common by age 70 . Almost all persons by age 40 have some pathologic change in the weight-bearing joint. $25 \%$ of females and $16 \%$ males have symptomatic OA. This disease has been described in Ayurveda from ancient times. The disease Arthritis causes work disability. It limits everyday activities such as walking, dressing, bathing etc, thus making individuals handicapped. No treatment is available which can prevent the disease process. In western medical science, mainly analgesics, antiinflammatory drugs or surgery are the options for the treatment of Osteoarthritis; don't provide remarkable recovery but causes great adverse effect. Researchers are trying their level best for making drugs that can prevent or slow down or reverse joint damage. Panchakarma therapy is one of the important branches of Ayurveda, which deals mainly with the purification of the aggravated Doshas from the human system. This is the reason behind the selection of the topic entitled "A COMPARATIVE CLINICAL STUDY OF MATRA VASTI AND PICHU WITH RASNA TAILA IN SANDHIGATA VATA W.S.R TO OSTEOARTHRITIS".
\end{abstract}


We have used Panchakarma treatment procedure. Panchakarma treatment is believed to help in the radical elimination of the disease-causing factors and maintain the equilibrium of doshas. The selection of Matravasti and pichu both are based on repeated recommendations of different Acharyas on Sandhigatavata. We used Rasna taila.

Keywords: Sandhigata vata, Osteoarthritis, MatraVasti, Pichu, Rasna taila

\section{INTRODUCTION}

Ayurveda is the science of life. It deals with the total creation with special emphasis on the biology of life. The chief objects laid down before this science is the preservation of health and prevention of disease. It envisages total welfare of the living being and so the term Ayurveda, the science of life is employed ${ }^{1}$. According to Ayurveda, freedom from disease is not only health. To be healthy, a person should be happy mentally, physically, socially and also spiritually ${ }^{2}$. The imbalance of Doshas is termed as Roga(disease). Among Tridosha, Vata is the strongest of all doshas and it causes a large number of diseases. Sandhigata Vata is one of the most prevalent joint diseases in the population $^{3}$. When Vata is localised in Sandhi (bony joint) it destroys the actions of the joints and gives rise to pain and swelling them ${ }^{4}$. Sandhigata vata is described under Vatavyadhi. In Vriddhavastha, all Dhathus(tissues) undergo Kshaya(decrease), thus leading to Vata prakopa(aggravate) and making individuals prone to many diseases. Among them, Sandhigata Vata stands top of the list. Acharya Charaka was the first person who described the disease separately named "Sandhigata Anila" but has not included under 80 types of Nanatmaja Vyadhi. So, in Sandhigata Vata, the Major symptoms are Shoola (Pain), Akunchan Prasaran janya Vedana (Pain during knee movement), Shotha (Swelling), Vata Poornadrutis Parsha (Ch. Chi. 28/37) etc ${ }^{5}$. According to signs and symptoms, it is correlated with Osteoarthritis. Osteoarthritis is a degenerative joint disease involving the weight-bearing joint ${ }^{6}$. Osteoarthritis (OA) is by far the most common form of arthritis. It is strongly associated with ageing and is a major cause of pain and disability in older people. Osteoarthritis is characterised by focal loss of articular cartilage, subchondral osteosclerosis, osteophyte formation at the joint margin, and remodelling of joint contour with enlargement of affected joints. Inflammation can occur but is not a prominent feature. Joint involvement In OA follows a characteristic distribution, mainly targeting, the hips, knees, PIP and DIP joints of the hands, neck and lumbar spine ${ }^{7}$. Till to date Sandhigata Vata is a challenging disease and is the number one cause of disability in industrialized countries. To date, no medicine is available which prevents or reverses or blocks the disease process. Treatment that slows down or halts disease progression is critically needed. Overall, we can say that rukshata(dryness), laghuta(lightness), kharata(roughness) \& sheetata (cold quality) are increased in Sandhigata Vata, here we need to plan a medicine which are having Tikta rasa (bitter taste), Guru(heaviness) \& Snigdha guna(unctuousness), Ushna veerya(exothermic) \& Vata samaka properties. In Ayurveda, there are multiple medicines having similar Guna (physical property) Dharma which cures Sandhigata vata \& Rasna taila is an important medicine among them.

Disease Review-: Sandhigatavata is one of the most prevalent joint diseases in the population. Basically, it is a degenerative process disease. Ayurveda has mentioned various regenerative 'therapeutic measures' to tackle this problem. it is being described in detail. Any disturbance in the fundamental configuration of Dhatus(tissues) which may lead to their malfunctioning is called Vikara, Vyadhi or disease and Sandhigatavata are one of the Vata Vikara (Ch. Su. 9/4). The term Sandhigatavata has its origin from a combination of three words viz 'Sandhi', 'Gata' \& 'Vata' (Siddhanta Nidan 8/513). Sandhigatavata is mentioned under Vatavyadhi by all Acharya, Acharya Charaka has said it is Sandhigata Anil (Ch. Chi. 
28137). Acharya Vagbhatta has said Vatavyadhi as "Maharoga" (A.H, Ni. S -1/11-15) Acharya Sushruta has described Pain (Shula), Swelling (Shotha) and Diminution of the movements at the joints involved (Hanti Sandhigatah) as symptoms of Sandhigatavata (Su. Ni. 1/28-29). It deals with Ayurvedic as well as modern points of view. No specific Samprapti (story of the disease) has been explained for Sandhigatavata. So, it can be said that the Samprapti of Sandhigatavata is the same as that of the general Samprapti of Vatavyadhi. Acharya Charaka has mentioned that Nidana Sevana (causative factor) aggravates Vata and this Prakupita(aggravated) Vata gets accumulated in Rikta Srotas (channels)and gives rise to various generalized and localized diseases (Ch. Chi. 28/18).

Osteoarthritis is the most common articular disorder that begins asymptomatically in the $2^{\text {nd }}$ and $3^{\text {rd }}$ decades and is extremely common by age 70 . Almost all persons by age 40 have some pathologic change in the weight-bearing joint. The disease Osteoarthritis may be regarded as a reward of longevity. It seems the man has paid price for standing on hind limbs in form of osteoarthritis of weight-bearing joints of the body.

This research topic was on sandhigata vata. It is a challenging disease for the physician due to its chronicity morbidity, complication periodic fluctuation and major for the loss of millions at working days, annually resulting in huge loss of national economy. So, there is a need to explore the potentiality to tackle this problem in the Ayurvedic way.

RASNA TAILA IN SANDHIGATA VATA W.S.R TO OSTEOARTHRITIS" is selected for the present $\mathrm{Kha}$ vaigunya (defect in channels). Also, it should have Rasayana(rejuvenation) property to overcome Dhatukshaya (decrease of tissues). Here is "A COMPARATIVE CLINICAL STUDY OF MATRA VASTI AND PICHU WITH study which can serve above needs to treat the disease Sandhigata Vata (Osteoarthritis).

\section{Aim \& Objectives of this work}

- To observe the effect of Rasna Taila with Matra Vasti in Sandhigata Vata.

- To observe the effect of Rasna Taila with Pichu in Sandhigata Vata.

- $\quad$ To observe the effect of Rasna Taila with Matra Vasti \& Pichu in Sandhigata Vata.

- To compare the Difference of Results in the above Treatment Groups.

\section{Materials and Methods}

Selection of Patients- Complete 90 cases of 'Sandhigatavata (Osteoarthritis) were selected irrespective of gender, religion, habitat, economic status, occupation etc. from the OPD and IPD of the Institute of Post Graduate Ayurvedic Education \& Research at SVSP Hospital in Kolkata, West Bengal. All the participants were registered at the Institute of Post Graduate Ayurvedic Education \& Research at SVSP Hospital in Kolkata, West Bengal for final evaluation. The study started in Nov 2018 and was completed in Sept 2020.

To assess the effect of therapy objectively, all the signs and symptoms were given scoring depending upon their severity.

\section{Inclusion Criteria:}

- Patients should be between age Group 40-70 years

- Patients are willing to participate in the study.

- Patients without any Anatomical Deformity should be included.

- Patients with the symptoms of Shoola, Akunchan PrasaranjanyaVedana, Shotha, Vata Poornadrutis Parsha etc.

\section{Exclusion Criteria:}

- Age below 40 years and above 70 years.

- Pregnancy \& Lactation

- Diabetes mellitus \& Hypertension

- Heart disease \& Renal pathology

- Past history of Koch's

- Carcinoma \& Gout 


\section{Sampling Design}

This study was performed in three treatment groups as follows-

\begin{tabular}{|l|l|l|}
\hline Treatment group & No. of Participants & \multicolumn{1}{c|}{ Treatment Schedule } \\
\hline Group A & 30 Participants & Matra Vasti along with Rasna taila. \\
\hline Group B & 30 Participants & Pichu along with Rasna Taila. \\
\hline Group C & 30 Participants & Matra Vasti and Pichu along with Rasna Taila. \\
\hline
\end{tabular}

\section{Objective Parameters:}

Following objectives \& laboratory parameters were taken in the present research programme-

a. Blood for TC, DC, ESR, $\mathrm{Hb} \%$

b. Blood for FBS \& PPBS

c. X-ray of affected Joint

d. Serum Creatinine \& Blood Urea All Laboratory investigations were done before \& after treatment.

\section{Statistical Analysis:}

Data was presented as mean, \pm Standard Deviation (SD), \pm Standard Error (SE). The Student Paired " $t$ " test was used independent Groups for Parametric Variables.

\section{Drug Review:}

Here the research drug Rasna Taila was taken (C. Chi/28/165-166)

The trial drug Rasna taila dominant of Tikta Rasa, UshnaVirya which facilitates increase Dhatvagni (metabolic stage), and nutrition and stableness of all the Dhatus, specially Asthi(bone) and Majja (bone marrow) Dhatu. The drug is having Dipana(appetizing), Pachana(digestive), Rochana (improves teste), Jvaraghna (Anti-Pyretic) and Dahaprashamana (reduce burning sensation) properties which help in the improvement of general condition, it is Balavardhaka (Increase strength), Varna Vardhak (Increase Complexion), \& AyuVardhak (Increase life span $)^{8}$. In this present study, Rasnataila contains 12 ingredients that have various types of actions in the body. Most of these ingredients are having Tikta Rasa, UshnaVirya and Madhura(sweet) and Katu(pungent)Vipaka (post-digestive effect). Virya is the most important part of Rasnataila. It is the potency by which the drug acts in the body.

Rasnataila contains Tikta Rasa which increases the Dhatvagni (metabolic stage). As Dhatvagni increase, the nutrition of all the Dhatus will be increased. As a result, Asthi Dhatu, Majja Dhatu may get stable and Asthi Dhatu and Majja Dhatu Kshaya will be decreased. So, degeneration in the Asthi Dhatu may not occur rapidly. It can be said, it slows down the degeneration processes.

SandhigataVata is MadhyamaRoga Margagata Vatika disorder in which vitiated Vata gets lodged in Sandhi. Hence to treat SandhigataVata drugs acting on both Vata and Asthi should be selected. According to Charaka, in Vatika disease, the treatment should be given by Rasna taila ${ }^{9}$. In Rasna taila predominance of Tikta Rasa is there.

Rasana taila is having Lekhana property (scraping out the cholesterol), so it helps in the weight reduction of the patients and helps in the management of Osteoarthritis. Rasna taila is also having Jwaraghna and DahaPrashamana (reduce burning sensation) properties that may act as an anti-inflammatory agent and can reduce the pain and swelling of the joints.

Rasnataila is Vata-pittashamaka, Balya (increase strength), Agnivardhaka (increase digestive capacity), Madhura, Saumya, Sheeta Virya(endothermic), Shula(pain), Jwarahara (reduce fever), Vrishya (increases sexual desire) and Vayasthapaka (prevent ageing) also. Thus, it specifies Vata, improves the general condition of the body and acts as a rejuvenator of the body. Thus, helps in the Samprapti Vighatana (evolution of diseases) of the Sandhigata Vata. Taila is having a property like Yogavahi which helps increase the bioavailability of other drugs without losing its property. Taila also contains many vitamins like thiamin, niacin, vitamin A, Folic acid ${ }^{10}$ which plays an important role to utilize calcium and phosphorous in blood and bone building.

Due to the Ushna property of Rasnataila, it is one of the major Vatashamaka Dravya. Due to its Ruksha 
and Vishada Guna(clearness), it acts as a Medohara (fat loss). According to Sushruta Guduchi have Lekhana property which helps in reducing body weight. Due to its Kasaya Rasa(astringent), it acts as a Deepana. Thus, help in the improvement of the general condition of the patient. Guduchi also acts as $R a$ sayana properties which may help to prevent any degenerative changes in the body.

Pharmacologically Guduchi, Devadaru, Rasna, Aswagandha, Sarala, Tiltaila, kundru, Tagara have the properties of anti-inflammatory, immunomodulatory and anti-lipidaemic action.

In clinical use, this drug does not show any kind of adverse effect. In the present study, therapeutic values obtained clinically and statistically are acceptable. Its production cost is very less, and it is affordable to the entire category of people in the society. So, this drug can be considered under a preventive and curative measure in Sandhigata Vata.

\section{Criteria for Assessment:}

- To assess the effect of therapy objectively, all the signs and symptoms were given scoring depending upon their severity.

\section{Sign \&Symptoms}

* Sandhi Shula:

- No pain

Score

- Mild pain

- Moderate pain but no difficulty in walking -

- Slight difficulty in walking due to pain - 3

- Severe difficulty in walking

* Sandhishotha:

- No swelling

- Slight swelling

- Moderate swelling

$-1$

- Severe Swelling

$-2$

* Sandhigraha:

- No Stiffness

- Mild stiffness

$-0$

- Moderate stiffness

$-1$

- Severe difficulty due to stiffness

$-2$

- Severe stiffness more than 15 minutes

\section{Akunchana Prasaranjanya Vedana:}

- No pain $-0$

- Pain without winching of face

- Pain with winching of face

- Prevent complete flexion

- Does not allow passive movement

* Sparshashayata:

- No tenderness

- Patient says tenderness

- Winching of face on touch

- Does not allow to touch the joint

* Sandhisphutana:

- No crepitus

- Palpable crepitus

- Audible crepitus

* Dosha and Dushya Dushti:

- Presence of symptoms before treatment - 2

- Improvement in symptoms

- Absence of symptoms after treatment

$-0$

- No change after treatment

TOTALEFFECTOFTHERAPY:

- Complete Remission : $100 \%$

- Maximum Improvement: $>75$ to $<100 \%$

- Moderate improvement: $>50$ to $75 \%$

- Mild improvement:>25 to50\%

- No improvement : 0-25\%

\section{GENERAL OBSERVATIONS}

- Hence, the total number of patients registered in the present study was 127, so observation of 90 Patients and results of 90 patients' statistical analysis are given below.

- It was found that a maximum number of patients i.e., $60.00 \%$ belonged to the age group of $61-$ 70years, followed by $25.55 \%$ patients to $51-60$ years, and lastly $14.44 \%$ patients belonged to 40 -50 years of age group.

\section{EFFECT OF THERAPY}

The study was mainly based on the clinical assessment of the aforesaid sign and symptoms that are mentioned in the material and methods. Effect of therapy was assessed based on scoring, blood routine examination mainly ESR, $\mathrm{Hb} \%$, joint examination, walking and climbing stair time, before and after the treatment. 
Group A: Effect of chief complaints in the patients of Sandhigata Vata

\begin{tabular}{|l|c|c|c|c|c|c|c|c|}
\hline Symptoms & \multicolumn{2}{|c|}{ Mean Score } & $\begin{array}{c}\text { \%Of } \\
\text { Relief }\end{array}$ & S.D. & S.E. & 'df' & 't' & P \\
\cline { 2 - 11 } & B.T. & A.T. & & & & \\
\hline Sandhishula & 2.38 & 0.54 & 77.41 & 0.54 & 0.11 & 25 & 16.82 & $<0.001$ \\
\hline Sandhishotha & 1.50 & 0.17 & 88.89 & 0.48 & 0.11 & 17 & 12.09 & $<0.001$ \\
\hline Akunchana Prasarana Vedana & 1.80 & 0.40 & 77.78 & 0.58 & 0.11 & 24 & 12.73 & $<0.001$ \\
\hline Sandhisphutana & 1.91 & 0.65 & 65.90 & 0.45 & 0.09 & 22 & 14.00 & $<0.001$ \\
\hline Sandhisparsasahatva & 1.44 & 0.12 & 91.30 & 0.60 & 0.15 & 15 & 08.73 & $<0.001$ \\
\hline Sandhigraha & 1.44 & 0.11 & 92.30 & 0.50 & 0.17 & 08 & 07.82 & $<0.001$ \\
\hline
\end{tabular}

In this group Effect of therapy on Sandhishula was found at $77.41 \%$ \& the Percentage of relief of Sandhishotha i.e., 88.89\%, Akunchana Prasaranajanya Vedana $77.78 \%$, Sandhisphutana $65.90 \%$ and San- dhisparsha Sahyata 91.30\%, Sandhigraha was $92.30 \%$ of relief. The above results are statistically highly significant at the level of $\mathrm{P}<0.001$.

Group B: Effect of chief complaints in the patients of Sandhigata Vata

\begin{tabular}{|l|c|c|c|c|c|c|c|c|}
\hline \multirow{2}{*}{ Symptoms } & \multicolumn{2}{|c|}{ Mean Score } & \% Of & S.D. & S.E. & 'df' & 't' & P \\
\cline { 2 - 9 } & B.T. & A.T. & Relief & & & & & \\
\hline Sandhishula & 2.29 & 0.71 & 68.75 & 0.65 & 0.17 & 13 & 09.23 & $<0.001$ \\
\hline Sandhishotha & 1.90 & 0.30 & 84.21 & 0.52 & 0.16 & 09 & 10.00 & $<0.001$ \\
\hline Akunchana Prasarana Vedana & 1.64 & 0.45 & 72.22 & 0.40 & 0.12 & 10 & 9.83 & $<0.001$ \\
\hline Sandhisphutana & 1.67 & 0.83 & 50.00 & 0.39 & 0.11 & 11 & 7.54 & $<0.001$ \\
\hline Sandhisparsasahatva & 1.50 & 0.25 & 83.33 & 00.50 & 0.25 & 03 & 5.00 & $>0.05$ \\
\hline Sandhigraha & 1.83 & 0.17 & 90.90 & 0.52 & 0.21 & 05 & 7.95 & $<0.001$ \\
\hline
\end{tabular}

In this group percentage of relief of Sandhishula 68.75\%, Sandhishotha 84.21\%, Akunchana Prasaranajanya Vedana $72.22 \%$, Sandhisphutana $50.00 \%$,
Sandhigraha $90.90 \%$ was found highly significant at the level of $\mathrm{P}<0.001$. A significant result was found in Sparshasahyata i.e., $83.33 \%$ at the level of $\mathrm{P}<0.05$.

Group C: Effect of chief complaints in the patients of Sandhigata Vata

\begin{tabular}{|l|c|c|c|c|c|c|c|c|}
\hline \multirow{2}{*}{ Symptoms } & \multicolumn{2}{|c|}{ Mean Score } & \%Of & S.D. & S.E. & 'df' & 't' & P \\
\cline { 2 - 10 } & B.T. & A.T. & Relief & & & & & \\
\hline Sandhishula & 2.37 & 0.55 & 77.40 & 0.54 & 0.11 & 25 & 16.82 & $<0.001$ \\
\hline Sandhishotha & 1.49 & 0.18 & 88.89 & 0.48 & 0.11 & 17 & 12.09 & $<0.001$ \\
\hline Akunchana Prasarana Vedana & 1.79 & 0.41 & 77.79 & 0.58 & 0.11 & 24 & 12.73 & $<0.001$ \\
\hline Sandhisphutana & 1.90 & 0.66 & 65.91 & 0.45 & 0.09 & 22 & 14.00 & $<0.001$ \\
\hline Sandhisparsasahatva & 1.43 & 0.13 & 91.30 & 0.60 & 0.15 & 15 & 08.73 & $<0.001$ \\
\hline Sandhigraha & 1.43 & 0.12 & 92.31 & 0.50 & 0.17 & 08 & 07.82 & $<0.001$ \\
\hline
\end{tabular}

In this group percentage of relief in Sandhishula 77.40\%, Sandhishotha 88.89\%, Akunchana Prasaranajanya Vedana $77.79 \%$, Sandhisphutana $65.91 \%$,
Sandhigraha $92.31 \%$ was found highly significant at the level of $\mathrm{P}<0.001$. A significant result was found in Sparshasahyata i.e., $91.30 \%$ at the level of $\mathrm{P}<0.05$. 
Effect of therapy on walking and climbing stair:

\begin{tabular}{|c|c|c|c|c|c|c|c|c|c|}
\hline \multirow[t]{4}{*}{ Symptoms } & \multicolumn{3}{|c|}{ Group A } & \multicolumn{3}{|c|}{ Group B } & \multicolumn{3}{|c|}{ Group C } \\
\hline & \multicolumn{2}{|c|}{ Mean Score } & \multirow{3}{*}{$\begin{array}{l}\text { \%Of } \\
\text { Relief }\end{array}$} & \multicolumn{2}{|c|}{ Mean Score } & \multirow{3}{*}{$\begin{array}{l}\% \text { Of } \\
\text { Relief }\end{array}$} & \multicolumn{2}{|c|}{ Mean Score } & \multirow{3}{*}{$\begin{array}{l}\text { \%Of } \\
\text { Relief }\end{array}$} \\
\hline & \multirow{2}{*}{ B.T. } & \multirow{2}{*}{ A.T. } & & & & & & & \\
\hline & & & & B.T. & A.T. & & B.T. & A.T. & \\
\hline $\begin{array}{l}\text { Walking time in sec. } \\
\text { (30meters) }\end{array}$ & 43.11 & 38.23 & 11.15 & 40.07 & 37.93 & 05.34 & 43.10 & 38.24 & 11.16 \\
\hline $\begin{array}{l}\text { Climbing up and down- } \\
\text { stairs in sec.(22stairs) }\end{array}$ & 46.92 & 41.35 & 11.88 & 44.78 & 40.71 & 09.09 & 46.91 & 41.36 & 11.89 \\
\hline
\end{tabular}

In the case of walking time in group A, the percentage of improvement was found $11.15 \%$ that shows a highly significant result. In group B percentage of improvement i.e., $05.34 \%$ and in group $\mathrm{C}$ percentage of improvement i.e., $11.16 \%$.
In the case of climbing time in group A, the percentage of relief was $11.88 \%$. In the case of group B percentage of improvement was $09.09 \%$ and in group $\mathrm{C}$ percentage of improvement was $11.89 \%$.

Effect of therapy on Joint Examination: Knee Joint Flexion in degree

\begin{tabular}{|c|c|c|c|c|c|c|c|c|c|}
\hline \multirow[t]{3}{*}{ Joint Examination } & \multicolumn{3}{|c|}{ Group A } & \multicolumn{3}{|c|}{ Group B } & \multicolumn{3}{|c|}{ Group C } \\
\hline & \multicolumn{2}{|c|}{ Mean Score } & \multirow[t]{2}{*}{$\%$ Of Relief } & \multicolumn{2}{|c|}{ Mean Score } & \multirow[t]{2}{*}{ \% Of Relief } & \multicolumn{2}{|c|}{ Mean Score } & \multirow[t]{2}{*}{$\%$ Of Relie } \\
\hline & B.T. & A.T. & & B.T. & A.T. & & B.T. & A.T. & \\
\hline Left & 74.58 & 101.67 & 36.31 & 79.61 & 101.15 & 27.05 & 74.57 & 101.69 & 36.31 \\
\hline Right & 66.14 & 97.50 & 47.42 & 83.75 & 100.62 & 20.15 & 66.13 & 97.51 & 47.43 \\
\hline
\end{tabular}

In group $\mathrm{A}$, the left knee joint flexion percentage of relief was $36.31 \%$, while the right knee joint flexion was $47.42 \%$.

In the case of group B, left knee joint flexion, the percentage of relief was found $27.05 \%$ and Right knee joint flexion, improvement was found $20.15 \%$. In group $\mathrm{C}$, the left knee joint flexion percentage of relief was $36.31 \%$, while the right knee joint flexion was $47.43 \%$.

Effect of Therapy on Laboratory Investigation:

In group A, the percentage of increased haemoglobin
$06.38 \%$ and percentage of decreased ESR $28.28 \%$ of studied patients was found statistically highly significant result at the level of $\mathrm{P}<0.001$.

In group B, the Percentage of increased haemoglobin was found $07.68 \%$ and ESR decreased by $07.93 \%$. both the above data shows highly significance at the level of $\mathrm{P}<0.001$.

In group $\mathrm{C}$, the Percentage of increased haemoglobin was found at $06.38 \%$ and ESR decreased $28.29 \%$. Both the above data shows highly significance at the level of $\mathrm{P}<0.001$.

TOTAL EFFECT OF THERAPY (In all Groups)

\begin{tabular}{|l|c|c|c|c|c|c|}
\hline Gradation & \multicolumn{2}{|c|}{ Group A } & \multicolumn{2}{c|}{ Group B } & \multicolumn{2}{c|}{ Group C } \\
\hline No. of Pts. & $\%$ & No. of Pts. & $\%$ & No. of Pts. & $\%$ \\
\hline Complete Remission (100\%) & 04 & 13.33 & 00 & 00.00 & 05 & 16.67 \\
\hline Maximum Improvement (>75to 99\%) & 16 & 53.33 & 06 & 20.00 & 21 & 70.00 \\
\hline Moderate Improvement (>50-75\%) & 10 & 33.33 & 22 & 73.33 & 04 & 13.33 \\
\hline Mild Improvement (>25-50\%) & 00 & 00.00 & 02 & 06.67 & 00 & 00.00 \\
\hline No Improvement (0-25\%) & 00 & 00.00 & 00 & 00.00 & 00 & 00.00 \\
\hline
\end{tabular}


In group A, $13.33 \%$ of patients achieved complete remission, while $53.33 \%$ of patients obtained maximum improvement, whereas $33.33 \%$ moderate improvement was also reported. No patient was observed under mild improvement in the present clinical study.

In group B $20.00 \%$ of patients had maximum improvement, while moderate improvement was found in $73.33 \%$ patients and $06.67 \%$ patients got mild improvement.

In group C $16.67 \%$ of patients achieved complete remission whereas $70.00 \%$ of patients had maximum improvement, while moderate improvement was found in $13.33 \%$ of patients.

In the present clinical research work, no patient was observed in an unchanged condition.

The above-mentioned data shows that patients treated with both Matra Vasti \& Pichu with Rasna Taila for 15days i.e., group $\mathrm{C}$ has provided better relief in the disease Sandhigata Vata (Osteoarthritis).

The results in all three groups proved to be highly effective and also statistically highly significant in different subjective and objective parameters. The result of group $\mathrm{C}$ was better. It may be due to the following causes-

- Here patients were treated with both MatraVasti \& Pichu with Rasna Taila for 15 days.

- Patients were treated with both Vasti and Local application of the drugs.

- Local application of Abhyanga(massage) and Nadi-Sweda (tube sudation) leads to vasodilatation of the local area Which facilitates increased blood supply. As a result, joints get more nourishment and their primary and accessory structure become strong and help in early recovery. At the same time, increased circulation provides discarding of the local tissue metabolic waste products helps in tissue rejuvenation and thus promote early recovery.

- Local application of Rasna Taila Snehana facilitates absorption of the medicine through the skin, helps in the improvement of joint condition. The increased local blood supply also facilitates the Matra Vasti to reach the site of action easily.

- So, when the trial drug was added along with Abhyanga and Nadi Sweda the result proved to be more significant.

\section{SUMMARY}

Any disturbance in the fundamental configuration of Dhatus which may lead to their malfunctioning is called Vikara(disease). Sandhigata Vata is one of the VataVikara. SandhigataVata is Asadhya Vyadhi(incurable). Usually, it happens from Madhya Vaya (middle age).

In the present study, an attempt has been made to SandhigataVata with Osteoarthritis due to the presence of several similar types of signs and symptoms of both cases.

Considering the importance of the disease the present study has been carried out with the entitled "A COMPARATIVE CLINICAL STUDY OF MATRA VASTI AND PICHU WITH RASNA TAILA IN SANDHIGATA VATA W.S.R TO OSTEOARTHRITIS."

\section{DISCUSSION}

The logical interpretation of the results obtained in the clinical study, based on Ayurvedic and modern principles. The conclusion drawn from the observations and results is presented hereunder.

- In the present study, the majority of the patients belonged to the age group $61-70$ years $(60.00 \%)$. The majority of the patients were female (74.44\%), $82.22 \%$ patients were Hindu, $83.33 \%$ were married, $45.55 \%$ patients were having education up to the primary level. $61.11 \%$ of patients were housewives. $78.88 \%$ of patients were belonging to a lowermiddle-class, $58.88 \%$ of patients were residing in rural areas. All the patients were belonging to Anup Desha, $95.55 \%$ of patients were mixed vegetarian.

- In cardinal symptoms Sandhishula was found in all the patients, Sandhisphutana was found in $26.67 \%$, Akunchana Prasaranajanya Vedana was found in $47.78 \%$ of patients. Sandhishotha was present in $72.22 \%$ of patients and Sparsha Asahyata in 38.88\% of patients, Vata Purana Druti Sparsha 32.22\%. Associated symptoms obtained were 
Vibandha(constipation) (32.22), Adhamana (bloating of abdomen) (31.11\%), Nidralpata (insomnia) (25.55\%), Daurbalya (weakness) (40.00\%).

- In Dosha Dusti, each Vataprakopa (aggravation of Vata) and Vatavriddhi (an increase of Vata) was found in $100 \%$ of patients. Pittavriddhi ((an increase of pitta) was found in $42.22 \%$ and Pittaprakopa (aggravation of pitta) in $35.56 \%$. Asthivaha and Majjavaha Srotodushti (vitiated channel) were found in all the patients. Mamsavaha Srotodushti in $42.22 \%$, Medovaha Srotodushti in 48.89\%, Raktavaha Srotodushti in $57.78 \%$.

Effect of therapy on Sandhishula was found $77.41 \%$ of relief in group A Percentage of relief of Sandhishotha i.e., 88.89\%, Akunchana Prasaranajanya Vedana 77.78\%, Sandhisphutana $65.90 \%$ and Sandhisparsha Sahyata 91.30\%, Sandhigraha was $92.30 \%$ of relief. The above results are highly significantat the level of $\mathrm{P}<0.001$.

In group B percentage of relief of Sandhishula 68.75\%, Sandhishotha 84.21\%, Akunchana Prasaranajanya Vedana $72.22 \%$, Sandhisphutana 50.00\%, Sandhigraha $90.90 \%$ was found highly significant at the level of $\mathrm{P}<0.001$. A significant result was found in Sparsha Asahyata i.e., $83.33 \%$ at the level of $\mathrm{P}<0.05$.

In group C percentage of relief of Sandhishula 77.40\%, Sandhishotha 88.89\%, Akunchana Prasaranajanya Vedana $77.79 \%$, Sandhisphutana $65.91 \%$, Sandhigraha $92.31 \%$ was found highly significant at the level of $\mathrm{P}<0.001$. A significant result was found in Sparsha Asahyata i.e., $91.30 \%$ at the level of $\mathrm{P}<0.05$.

\section{Improvement on climbing stairs:}

In the case of climbing time in group a, percentage of relief was $11.88 \%$. Improvement was insignificant at the level of $\mathrm{P}>0.05$. In group $\mathrm{B}$ percentage of improvement was $9.09 \%$. This result shows statistical significance at the level of $\mathrm{P}<0.01$. In group $\mathrm{C}$ percentage of improvement was $11.89 \%$. This result shows statistical significance at the level of $\mathrm{P}<0.01$.

\section{Improvement on Joint Examination:}

In group A, the left knee joint flexion percentage of relief was $36.31 \%$, while the right knee joint flexion was $47.42 \%$ which is highly significant at the level of $\mathrm{P}<0.001$.

Hip Joint flexion (left), the percentage of relief was found $38.51 \%$ and hip joint flexion (right) percentage of relief was found $36.82 \%$, which is statistically highly significant at the level of $\mathrm{P}<0.001$.

In group B, left knee joint flexion, the percentage of relief was found $27.05 \%$. The improvement was highly significant at the level of $\mathrm{P}<0.001$. Right knee joint flexion, improvement was found $20.15 \%$. It shows a significant result at the level of $\mathrm{P}<0.01$.

Hip joint flexion (left), percentage of relief was found $18.85 \%$ which shows a highly significantresult at the level of $\mathrm{P}<0.001$. Hip joint flexion (right), percentage of relief was found $14.58 \%$.

In group $\mathrm{C}$, left knee joint flexion, the percentage of relief was found $36.31 \%$. The improvement was highly significant at the level of $\mathrm{P}<0.001$. Right knee joint flexion, improvement was found $47.43 \%$. It shows a significant result at the level of $\mathrm{P}<0.01$.

Hip joint flexion (left), percentage of relief was found $38.52 \%$ which shows a highly significantresult at the level of $\mathrm{P}<0.001$. Hip joint flexion (right), percentage of relief was found $36.83 \%$, improvement.

\section{Improvement on Laboratory Investigation:}

In group A, the percentage of increased haemoglobin $6.38 \%$ and percentage of decreased ESR $28.28 \%$ of studied patients was found statistically highly significant result at the level of $\mathrm{P}<0.001$.

In group $\mathrm{B}$, the percentage of increased haemoglobin was found $7.68 \%$ and ESR decreased $21.10 \%$. Both the above data shows highly significance at the level of $\mathrm{P}<0.001$.

In group $\mathrm{C}$, the percentage of increased haemoglobin was found $06.38 \%$ and ESR decreased $28.29 \%$. Both the above data shows highly significance at the level of $\mathrm{P}<0.001$.

\section{Total Effect of Therapy}

In group A, $13.33 \%$ of patients achieved complete remission, while $53.33 \%$ of patients obtained maximum improvement, whereas $33.33 \%$ moderate improvement was also reported.

In group B, $0.00 \%$ of patients had complete remission, $20.00 \%$ had maximum improvement, while 
moderate improvement was $73.33 \%$ and $06.67 \%$ of patients were a mild improvement.

In group $\mathrm{C}, 16.67 \%$ of patients had complete remission, $70.00 \%$ had maximum improvement, while moderate improvement was $13.33 \%$.

The above-mentioned data shows that Rasna Taila Pichu along with Matra vasti, local Abhyanga and Nadi Swedana i.e., group C has provided better relief in the disease Sandhigata Vata (Osteoarthritis) in the present study.

\section{CONCLUSION}

Sandhigata Vata vis-à-vis Osteoarthritis is multifactorial, non-inflammatory degenerative joint disorder. There was no apparent change was observed in the x-ray before and after treatment. According to the literary profile, this disease is Asadhya or incurable in nature, this is also supported by the recurrence of the same type of complaint in the patient included in the present clinical study. The medication can give only symptomatic relief for a certain period. Though the trial drug of the present clinical study that is Rasnataila proves to be an effective remedy for Sandhigata Vata. It shows better efficacy when applied with local Pichu, Matra Vasti, Abhyanga and Nadi Sweda. In the present study, the size of the sample was 90 patients and the period of study was limited. Hence it is difficult to draw a definite conclusion regarding this study. In this context, it is suggested that the study should be continued with a large sample and treatment for a longer duration. It is expected that the present study will disclose some definite clues to future researchers.

\section{REFERENCES}

1. Singh. R. H, Panchakarma Therapy, Reprint edition, Varanasi, Chowkhamba Sanskrit series office 2007, $\mathrm{Pg}-2$.

2. Sharma. K.R. \& Dash. Bhagwan, Caraka Samhita, Reprint edition, Varanasi, Chowkhamba Sanskrit Series Office 2016, VOL $-1^{\text {st }}$, Sutra sthana1/15, pg no 19

3. Babu Suresh S. Dr, The Principles and Practice of Kaya Cikitsa, Reprint edition, Varanasi, Chau- khambha Orientalia 2015 , Vol- $3^{\text {rd }}, 1^{\text {st }}$ chapter, pg-3, 22

4. Murthy Srikantha R.K. Prof, Susruta Samhita, Reprint edition, Varanasi, Chaukhambha Orientalia 2014, Vol-1 ${ }^{\text {st }}$, Nidana Sthana1/28, Pg no -464-465

5. Sharma. K.R \& Dash. Bhagwan, Caraka Samhita, Reprint edition, Varanasi, Chowkhamba Sanskrit Series Office, VOL $-5^{\text {th }}$, Cikitsa sthana 28/37, pg no 30

6. Patil Vasant Vaidya, A Guide to Ayurvedic Clinical Practice, Reprinted, Varanasi, Chaukhamba Sanskrit Pratishthan 2019,10 ${ }^{\text {th }}$ chapter, Pg-236

7. Davidson Stanley sir, Davidson's Principles \& Practice of Medicine, Reprinted, $22^{\text {nd }}$ Edition, An imprint of Elsevier Limited 2014, $25^{\text {th }}$ chapter, pg-1081

8. Kushwaha Singh Chandra Harish Vd., Caraka Samhita, Reprint Edition, Varanasi, Chaukhambha Orientalia 2017, Cikitsa sthana28/172 - 182, Pg no -761

9. Sharma. K.R \& Dash. Bhagwan, Caraka Samhita, Reprint edition, Varanasi, Chowkhamba Sanskrit Series Office 2015, VOL $-5^{\text {th }}$, Cikitsa sthana 28/ (157 1/2 - 164), Pg no -65

10. Paranjpe Prakash Dr., Indian Medicinal Plants Forgotten Healers A Guide to Ayurvedic Herbal Medicine, Varanasi, Chaukhamba Sanskrit Pratishthan 2012, Pg no-258

\section{Source of Support: Nil \\ Conflict of Interest: None Declared}

How to cite this URL: Nupur Biswas \& Kultar Singh: A Comparative Clinical Study Of Matravasti And Pichu With Rasna Taila In Sandhigatavata W.S.R To Osteoarthritis. International Ayurvedic Medical Journal \{online\} 2021 \{cited December 2021\} Available from: http://www.iamj.in/posts/images/upload/2975_2984.pdf 